\title{
EFFECT OF SOME GROWTH REGULATORS APPLIED TO A MULTIPLICATION AND ROOTING MEDIA ON MICROPROPAGATION AND ACCLIMATIZATION OF SOME CULTIVARS OF Rosa hybrida L. Hussein, H. A. A. \\ Veget. and Flor. Dept., Fac. of Agric., Mansoura Univ.
}

\section{ABSTRACT}

The present research was carried out to study the effect of BAP at $0.25,0.50$, 1.00 and $2.00 \mathrm{mg} / \mathrm{l}$ concentrations added to the multiplication medium and IAA at 0.1 , $0.3,1.0$ and $3.0 \mathrm{mg} / \mathrm{l}$ concentrations applied in rooting medium on the in vitro micropropagation and acclimatization under greenhouse conditions of Rosa hybrida L. plants. The rose cultivars used in this research were namely Athena, Diana and Red Success.

To evaluate the adaptation degree of different rose cultivars to culture medium composition, the shoot tips ( $15-20 \mathrm{~mm}$ length) were surface sterilized and cultured on the modified Quoirin \& Lepoivre (1977) medium used as proliferation medium supplemented with casein hydrolysate $(1.0 \mathrm{~g} / \mathrm{l})$, sucrose $(30.0 \mathrm{~g} / \mathrm{l})$, Difco agar $(8.0 \mathrm{~g} / \mathrm{l})$, gibberellic acid $\left(\mathrm{GA}_{3}\right)(1.0 \mathrm{mg} / \mathrm{l})$, BAP $(1.0 \mathrm{mg} / \mathrm{l})$ and IAA $(0.3 \mathrm{mg} / \mathrm{l})$. The proliferated shoots were excised and cultured on multiplication and rooting media. The obtained results indicated that Red success rose $\mathrm{cv}$. were the best to produce the highest rate of shoot proliferation, shoot multiplication, rhizogenesis values and survival percentage followed by Diana rose cv., while Athena rose was the lowest in this respect.

The obtained results showed that the best shoot multiplication was achieved in the culture medium containing 6-benzylaminopurine (BAP) $(1.0 \mathrm{mg} / \mathrm{l})$ and indole-3acetic acid (IAA) $(0.5 \mathrm{mg} / \mathrm{l})$ which produced the highest survival percentage, shoot initiation occurred within a few days, the highest percentage of explants which formed shoots, the highest number of multiplied shoots and the tallest multiplied shoots per explant.

The obtained results also indicated that the BAP concentration of the shoot multiplication medium affected rooting and survival percentages in the next stage of culture. Shoot tips formed on media which containing 0.25 and $0.50 \mathrm{mg} / \mathrm{l} \mathrm{BAP}$ rooted and acclimatized better than shoot tips formed on media containing 1.0 and $2.0 \mathrm{mg} / \mathrm{l}$ BAP.

Moreover, rooting of multiplied shoots was achieved on the same medium used in multiplication stage except for the macroelements of Quoirin \& Lepoivre (1977) medium used at half strength and sucrose at $20 \mathrm{~g} / \mathrm{l}$ and IAA $(0.3 \mathrm{mg} / \mathrm{l})$ which produced the highest rooting percentage, the highest number of roots per explant and the tallest roots per explant. The obtained results also revealed that fewer amount of IAA $(0.1$ $\mathrm{mg} / \mathrm{l})$ in the rooting media significantly improved plantlets acclimatization, and subsequently transferred to a mixture of peatmoss and perlite $(3: 1 \mathrm{v} / \mathrm{v})$ to greenhouse. The rooted plantlets survived Successfully and grew into normal plants.

\section{INTRODUCTION}

Development of procedures for rapid in vitro clonal propagation of rose may be of great commercial value to the rose industry. Tissue culture techniques should minimize the time necessary for production of new cultivars into the commercial market and thus increase the availability of rose plants with improved horticultural characteristics. These techniques may be also of potential benefit for the mass propagation of existing commercial cultivars. 
After the first works of Elliot (1970) and Jacobs et al. (1969) on the in vitro development and rooting of rose shoot tips, many studies were tried to find efficient methods to propagate lines of commercial varieties as mentioned by Hasegawa (1979), Skirvin and Chu (1979) and Martin et al. (1981). In the in vitro propagation process, it is important to establish which factors control the mechanism of shoot multiplication, root initiation on cultured shoot tips and which are for the successful transfer of plantlets obtained in vitro to soil. Some of these factors have been extensively studied: Cultures, media factors (e.g. nutritional or hormonal) and environmental factors. However, their functions can not be generalized to all plant species.

Successful application of micropropagation through tissue culturing of Rose genotypes is not general. It is problematic in case of some cultivars, particularly in the two last stages: rooting in vitro and acclimatization under greenhouse conditions. Some rose cultivars adapt well in the greenhouse up to $90 \%$ (Hasegawa, 1980; Khosh-Khui and Sink, 1982) but other recorded only $50 \%$ (Skirvin and Chu, 1979).

Accordingly, the objectives of this study were to examine the effect of BAP and IAA at different concentrations on shoots multiplication and rooting of shoot tips (from three rose cvs. namely Athena, Diana and Red Success) cultured in vitro to find out the most effective conditions to improve rooting percentage and raise plantlets acclimatization under greenhouse conditions.

\section{MATERIALS AND METHODS}

The Rosa hybrida L. (Fam. Rosaceae) cultivars of white colour cv. Athena, yellow colour cv. Diana and dark red colour cv. Red Success were examined in this study. The shoot tip explants (15-20 mm length) with $2-3$ nodes were taken from the shoots belonging to softwood stems which occupied middle position of plants grown in the greenhouse, were used as the explants in the experiments. The work was conducted during the period from June to December 1994 at the Tissue Culture Laboratories of the Obuda Farm of Floriculture and University of Horticultural, Budapest, Hungary.

Aseptic cultures established from the shoot tips were surface sterilized in three steps: 1) rinsed in a distilled water for 2 min., 2) immersion in calcium hypochlorite at 7\% containing few drops of Tween-20 wetting agent for 10 min. and 3) rinsing 4 times in a sterile distilled water changed for 2 min. each. To avoid the darkening of the explants, the sterilized materials were immersed in Polivinil Pirrolidon (PVP) soluble solution at a concentration 1\% for $10 \mathrm{~min}$.

Shoot tip explants (15-20 mm length) were obtained by removing 2 or 3 leaves and excising the terminal $4-7 \mathrm{~mm}$ of the shoot as were subjected to 4 tests in this study. The first test was concerned with culturing shoot tip explants on the proliferation medium of the three tested Rose cvs. which proliferated on the medium described by Quoirin \& Lepoivre (1977) and modified by (Hussein and Toth, 1993), supplemented with vitamins as described by Murashige and Skoog (1962), sucrose $(30,0 \mathrm{~g} / \mathrm{l})$, Difco agar $(8,0$ $\mathrm{g} / \mathrm{l})$, casein hydrolysate $(1,0 \mathrm{~g} / \mathrm{l})$, gibberellic acid $\left(\mathrm{GA}_{3}\right)(1, \mathrm{O} \mathrm{mg} / \mathrm{l})$, 6benzylaminopurine (BAP) $(1.0 \mathrm{mg} / \mathrm{l})$ and Indole-3-acetic acid (IAA) $(0.3 \mathrm{mg} / \mathrm{l})$.

The second test was carried out on the sterile shoot tips $(15-20 \mathrm{~mm}$ length) obtained from proliferated shoots and transferred onto multiplication 
media consisted of the mineral salt formulation of Quoirin and Lepoivre (1977) supplemented with vitamins as described by Murashige and Skoog (1962), sucrose $(30,0 \mathrm{~g} / \mathrm{l})$, Difco agar $(8,0 \mathrm{~g} / \mathrm{l})$, casein hydrolysate $(1,0 \mathrm{~g} / \mathrm{l})$, gibberellic acid $\left(\mathrm{GA}_{3}\right)(1,0 \mathrm{mg} / \mathrm{l})$ and 6-benzylaminopurine (BAP) tested at concentrations of $0.25,0.50,1.00$ and $2.00 \mathrm{mg} / \mathrm{l}$ in the presence of IAA at $0.50 \mathrm{mg} / \mathrm{l}$.

The third test was concerned with evaluating the effect of BAP concentrations of the shoot multiplication medium on the rooting and survival percentage of plantlets. Whereas, the shoot tip explants multiplied in the multiplication media containing different BAP concentrations at $0.25,0.50,1.0$ and $2.0 \mathrm{mg} / \mathrm{l}$ were transferred on rooting medium containing the same medium used in multiplication stage except for the macroelements of Quoirin \& Lepoivre (1977) medium used at half strength, vitamins as described by Murashige \& Skoog (1962), sucrose at $20 \mathrm{~g} / \mathrm{l}$, Difco agar (8,0 g/l), casein hydrolysate $(1.0 \mathrm{~g} / \mathrm{l})$ and $0.50 \mathrm{mg} / \mathrm{l} \mathrm{IAA}$. After two weeks, number of rooted shoots was recorded and were planted in a mixture of peatmoss and perlite $(3: 1 \mathrm{v} / \mathrm{v})$. Four weeks after acclimatization, the number of surviving plants was determined.

The last test was designed on the rooting tests. Shoot tip explants (15 $-20 \mathrm{~mm}$ length) excised from proliferated shoots were transferred on rooting media as in the third test containing different IAA concentrations at $0.1,0.3$, 1.0 and $3.0 \mathrm{mg} / \mathrm{l}$ for two weeks, the effect of IAA applied was studied in relation to shoots rooting and acclimatization of plantlets in the greenhouse. The $\mathrm{pH}$ was adjusted to 5.7 with $\mathrm{KOH}$ and $\mathrm{HCL}$ before agar was added. The culture medium was autoclaved at $120^{\circ} \mathrm{C}$ for $20 \mathrm{~min}$. At the end of the rooting period, rooting results were determined. Afterwards, rooted plants were planted into $5.7 \mathrm{~cm}$ plastic pots in a mixture of peatmoss and perlite $(3: 1 \mathrm{v} / \mathrm{v})$ and were kept under an intermittent mist for four weeks under greenhouse conditions. At this stage the shoots elongated few centimeters, and the number of surviving plants was recorded four weeks after transplantation.

In all above treatments, medium of $50 \mathrm{ml}$ was dispensed into $220 \mathrm{ml}$ jars for explant culture, one shoot tip explant was cultured per jar for the proliferation stage and 5 explants were cultured per jar for the multiplication and rooting stages. Cultures were maintained at $23^{\circ} \mathrm{C}$ under a constant fluorescent light (day light F-29) of 3000 Lux for $16 / 8$ hr day/night.

Throughout the shoots proliferation and multiplication stages of the present study, the following characters were recorded: number of days until appearance of visible formed shoots (day) and contamination percentage of shoot tip explant, four weeks later, survival percentage of cultured explants, percentage of explants which formed shoots, number of shoots per explant (shoot), length of shoots per explant $(\mathrm{cm})$ and the amount of callus formation at the shoot base were determined. During the root formation stage, number of days until appearance of visible formed roots was recorded. Two weeks after incubation the following observations were determined: percentage of explants which formed roots, number of roots per explant, Length of roots per explant $(\mathrm{cm})$, survival percentage of rooted plantlets and the amount of callus formation at the shoot base and after 4 weeks of acclimatization the survival percentage of rooted plantlets was recorded. 
A completely randomized design with 4 replicates was used throughout the experiments. Collected data were examined statistically using the computerized analysis of variance and Duncan's multiple range test procedures within the statistical analysis system, SAS (2000).

\section{RESULTS}

Shoots proliferation of Rose plants as affected by different cultivars:

Data in Table (1) showed that calcium hypochlorite at $7.0 \%$ for $10 \mathrm{~min}$. is a satisfactory sterilizing agent for shoot tip explants, since infection percentages ranged from 0.0 to $14.3 \%$ in the examined cultivars while, the differences were significant between the examined different cultivars. In addition, shoot tip explants of Athena and Diana rose cultivars grown on culture medium showed significantly lower survival percentage of $92.85 \%$ for each comparing with $96.11 \%$ of shoot tip explants of Red Success rose cv. Concerning number of days until appearance of visible formed shoots, the shoot tips of Red Success rose cv. produced the shoots significantly earlier within 9.30 days, while shoot tips of Athena rose cv. produced the shoots at very low frequency within 10.80 days. Not all cultured explants formed elongated shoots. However, shoot tips of Diana rose cv. grown on culture medium produced significantly higher percentage of explants which formed shoots (96.43\%). Number of shoots for all healthy explants showed differences between the different varieties. The significantly highest number of shoots (2.54 shoot) was produced by Red Success rose cv. while Diana rose cv. had the significantly lowest number of shoots (1.88 shoot). Moreover, shoot tips of Red Success rose cv. produced significantly the longest shoots $(1.71 \mathrm{~cm})$, while Athena rose $\mathrm{cv}$. had the significantly shortest shoots $(1.11 \mathrm{~cm})$. Shoot tips of Athena rose cv. produced hard green callus in a moderate size comparing with those of Diana and Red Success rose cvs. which produced hard green callus between little and moderate sizes.

\section{Shoots multiplication of Rose cultivars as affected by BAP concentrations :}

Data presented in Table (2) showed that, the multiplication rate appears to be determined by the cultivars and BAP concentrations. In this regard, shoot tips of Red Success rose cv. had significantly higher survival percentage $(98.95 \%)$ as compared with the other cultivars. In addition, there was a difference in emergencing time of shoots between explants obtained from different cultivars. The visible formed shoots occurred within a shorter time (10.42 days) with Red Success rose cv. While for Athena and Diana rose cvs., the time of emergence of visible formed shoots was significantly delayer at 11.24 and 10.86 days, respectively. Moreover, shoot explants of Red Success rose cv. gave significantly higher percentage of explants which formed multiple shoots (96.82\%) than Athena and Diana rose cvs. (88.13 and $90.12 \%$, respectively). It may be noted that explants of Red Success rose cv. produced the highest number of shoots (2.62 shoot) than Athena and Diana rose cvs. (2.18 and 2.33 shoot, respectively). 
J. Agric. Sci. Mansoura Univ., 32 (4), April, 2007

1 
Hussein, H. A. A

2 
Finally, shoot explants of Diana cv. produced significantly the tallest shoots $(1.09 \mathrm{~cm})$, while explants of Athena rose cv. produced the shortest ones $(0.83$ $\mathrm{cm})$. Moreover, a moderate size of hard dark-green callus appeared with all cultivars.

Data reported in same Table revealed that, the significantly highest survival percentage of explants were obtained on medium containing 0.25 , 0.50 and $1.0 \mathrm{mg} / \mathrm{l} \mathrm{BAP}(100 \%$ for each) than those grown on medium containing $2.0 \mathrm{mg} / \mathrm{l} \mathrm{BAP}(83.93 \%)$. In this concern, visible shoots formation occurred after 9.88 - 11.79 days depending on BAP concentrations. On medium containing $1.0 \mathrm{mg} / \mathrm{l} \mathrm{BAP}$, the visible formed shoots were produced significantly earlier with a fewer days ( 9.88 days). With gradual concentration increase of BAP, the percentage of explants, which started to form shoots gradually increased until $1.0 \mathrm{mg} / \mathrm{l} \mathrm{BAP}$. In this concern, the significantly highest percentages of explants which formed shoots (97.9\%) were obtained on medium containing $1.0 \mathrm{mg} / \mathrm{l} \mathrm{BAP}$ than those grown on medium containing $0.25,0.50$ and $2.0 \mathrm{mg} / \mathrm{BAP}(92.43,95.83$ and $80.60 \%$, respectively). The explants grown on medium containing $1.0 \mathrm{mg} / \mathrm{l} \mathrm{BAP}$ produced significantly the highest number of shoots (2.85 shoot), while the medium containing the higher concentration of BAP at $2.0 \mathrm{mg} / \mathrm{l}$ produced the lowest number of shoots (2.02 shoot). Explants grown on medium containing BAP at $1.0 \mathrm{mg} / \mathrm{l}$ produced significantly the tallest shoots $(1.14 \mathrm{~cm})$, while those grown on medium containing the lower concentration of BAP at $0.25 \mathrm{mg} / \mathrm{l}$ and higher concentration of BAP at $2.0 \mathrm{mg} / \mathrm{l}$ produced significantly shorter shoots $(0.93$ and $0.82 \mathrm{~cm}$, respectively). Shoot tips grown on medium supplemented with 0.25 and $0.50 \mathrm{mg} / \mathrm{l} \mathrm{BAP}$ produced hard green callus in a moderate size, while those grown on medium containing BAP at 1.0 and $2.0 \mathrm{mg} / \mathrm{l}$ produced hard green callus between moderate and profuse sizes.

Concerning the interaction effect, it was evident from the same Table that, the significantly highest survival percentages were obtained with shoot tips of Athena, Diana and Red Success rose cvs. grown on a media containing $0.25,0.50$ and $1.0 \mathrm{mg} / \mathrm{l} \mathrm{BAP}(100 \%$ for each, respectively) than those grown on a medium containing $2.0 \mathrm{mg} / \mathrm{l} \mathrm{BAP}(86.0,70.0$ and $95.8 \%$, respectively). Shoot tips of Red Success rose cv. grown on a medium containing $1.0 \mathrm{mg} / \mathrm{l} \mathrm{BAP}$ produced the visible formed shoots significantly earlier few days ( 9.13 days) than the other interactions. The shoot tips of Red Success rose cv. cultured on a medium containing $1.0 \mathrm{mg} / \mathrm{l} \mathrm{BAP}$ produced significantly higher percentage of explants which formed shoots $(98.90 \%)$ than the other interactions. Moreover, the shoot tips of Red Success rose cv. grown on a medium containing $1.0 \mathrm{mg} / \mathrm{l} \mathrm{BAP}$ produced significantly higher number of shoots (3.3 shoot) than the other interactions. Finally, the shoot tips of Diana rose $\mathrm{cv}$. grown on a medium containing $1.0 \mathrm{mg} / \mathrm{l} \mathrm{BAP} \mathrm{formed}$ significantly the tallest shoots $(1.35 \mathrm{~cm})$ than those of the other interactions.

\section{Rooting and Survival percentages of Rosa cultivars as affected by} different BAP concentrations:

Dealing with the effect of BAP concentrations of multiplication medium on the rooting and survival percentage of shoot explants, the data reported in Table (3) showed that, shoot explants of Red Success rose cv. produced 
significantly higher rooting percentage (66.0\%). While those of Athena rose cv. produced significantly lower rooting percentage (56.0\%). Moreover, shoot explants of all cultivars formed on the media containing the low BAP concentrations at 0.25 or $0.50 \mathrm{mg}$ produced significantly higher rooting percentages than those obtained from the media containing higher BAP concentrations at 1.0 or $2.0 \mathrm{mg} / \mathrm{l}$. Rooted plantlets of Red Success rose cv. gave significantly higher survival percentage $(70.3 \%)$ comparing with those of Athena and Diana rose which gave lower survival percentages (55.1 and $53.4 \%$, respectively). Regarding the survival percentage of rooted shoot tips, the shoot explants formed on media containing high BAP concentrations at 1.0 or $2.0 \mathrm{mg} / \mathrm{l}$ produced significantly lower survival percentage comparing with those formed on media containing the low BAP concentrations at 0.25 or $0.50 \mathrm{mg} / \mathrm{l}$. Regarding the interaction effect, it was found that shoot explants of Red Success rose cv. formed on the medium containing BAP at $0.50 \mathrm{mg} / \mathrm{l}$ produced significantly the highest rooting percentages (83.4\%) than those of the other interaction. In addition, the rooted shoot tips of Red success rose cv. formed on the medium containing BAP at $0.50 \mathrm{mg} / \mathrm{l}$ produced significantly the highest survival percentages (88\%) comparing with the other interactions. On the other hand, explants formed on media containing BAP at 0.25 or $0.50 \mathrm{mg} / \mathrm{l}$ induced callus in a moderate size while those grown on media containing BAP at 1.0 or $2.0 \mathrm{mg} / \mathrm{l}$ induced callus between moderate to profuse size.

Rooting percentage of Rose cultivars as affected by IAA concentrations:

Data presented in Table (4) showed that shoot explants of Red Success rose $\mathrm{cv}$. grown on the rooting medium produced significantly higher rooting percentage $(45.10 \%)$, than those of Athena rose cv. which had the lowest rooting percentage (35.93\%). In this respect it was observed that roots formation appeared after $10.22-12.47$ days from culturing on rooting media. Shoot tips of Diana rose cv. produced the visible root formation significantly earlier at a shorter time (10.22 days) while with Athena rose cv. the time of emergence of visible root formation was longer (12.47 days). Moreover, explants of Red Success rose cv. grown on rooting media produced significantly the highest number of roots (3.49 root) while those of Athena rose cv. produced the lowest number of roots (1.12 root). Shoot explants of Diana rose $\mathrm{cv}$. formed the tallest roots $(0.87 \mathrm{~cm})$, while those of Athena rose cv. were the shortest $(0.45 \mathrm{~cm})$. In addition, shoot tips of the three cultivars produced callus in a moderate size.

Data reported in the same Table indicated that shoot tips grown on rooting medium with $0.3 \mathrm{mg} / \mathrm{l}$ IAA produced significantly high rooting percentage $(65.6 \%)$ while, the lowest rooting percentages $(6.37 \%)$ were produced with the higher concentration of IAA at $3.0 \mathrm{mg} / \mathrm{l}$. Regarding roots initiation, the visible formed roots appeared within 9.04 - 13.14 days of culturing time. The roots which emerged significantly earlier (after 9.04 days) resulted from the explants grown on the rooting medium containing lower concentration of IAA at $0.1 \mathrm{mg} / \mathrm{l}$. But, rooting medium containing higher concentration of IAA at $3.0 \mathrm{mg} / \mathrm{l}$ significantly delays the time of appearance of the visible root formation (after 13.14 days). Number of roots per explant was gradually increased with increasing IAA concentration to $0.3 \mathrm{mg} / \mathrm{l}$ in the rooting medium. 
J. Agric. Sci. Mansoura Univ., 32 (4), April, 2007 T3 
Hussein, H. A. A

T4 
Shoot explants grown on rooting medium containing $0.3 \mathrm{mg} / \mathrm{IAA}$ produced the highest number of roots (2.89 root). However, the lowest number of roots (1.40 root) was produced with $3.0 \mathrm{mg} / \mathrm{IAA}$. It was clear that the root length decreased with the increase of IAA concentration. The shoot explants treated with $0.3 \mathrm{mg} / \mathrm{I}$ IAA gave the longest roots $(0.89 \mathrm{~cm})$. In contrast, the shoot explants treated with $3.0 \mathrm{mg} / \mathrm{l}$ IAA formed the shortest roots $(0.3 \mathrm{~cm})$ which were one third of the former.

Regarding the interaction, it was found that, the shoot tips of Diana rose $\mathrm{cv}$. grown on rooting medium containing $0.3 \mathrm{mg} / \mathrm{IAA}$ produced significantly the highest percentage of explants which formed roots $(80.60 \%)$ than the other interactions. However, the shoot tips of Diana rose cv. cultured on rooting medium containing $0.10 \mathrm{mg} / \mathrm{I} \mathrm{IAA}$ produced the visible root formation significantly earlier at the shorter time (8 days) than the other interactions. In addition, the shoot tips of Red Success rose cv. grown on a rooting medium containing $0.3 \mathrm{mg} / \mathrm{l}$ IAA produced significantly the highest number of roots (4.97 root) comparing with the other interactions. Finally, the shoot explants of Diana rose cv. grown on a rooting medium containing $0.30 \mathrm{mg} / \mathrm{I}$ IAA formed significantly taller roots $(1.22 \mathrm{~cm})$.

\section{Survival percentage of Rosa cultivars as affected by different IAA concentrations:}

Data presented in the same Table showed that, the rooted plantlets of Red Success rose cv. grown on a mixture of peatmoss and perlite had significantly higher survival percentages (48.4\%) than those of Athena and Diana rose cvs. $37.5 \%$ for each). The survival percentages of rooted plantlets gradually decreased as the concentration of IAA was increased. The survival percentages of rooted plantlets reached a tremendous percentage of $66.8 \%$ when the plantlets were rooted on a rooting medium containing $0.1 \mathrm{mg} / \mathrm{I}$ IAA than those rooted with $0.3,1.0$ or $3.0 \mathrm{mg} / \mathrm{l}$ IAA $(46.9,32.0$ or $18.9 \%$, respectively). Regarding the interaction effect, it was found that, the shoot tips of Red Success rose cv., which rooted on a rooting medium containing $0.1 \mathrm{mg} / \mathrm{I}$ IAA produced significantly higher survival percentage (68.75\%) than the other interactions. Finally, shoot explants grown on a rooting medium containing IAA at 0.1 , 0.3 and $1.0 \mathrm{mg} / \mathrm{l}$ produced callus in a moderate size only, while those grown on a rooting medium containing IAA at $3.0 \mathrm{mg} / \mathrm{l}$ produced callus in a profuse size.

\section{DISCUSSION}

Although Successful micropropagation of a large range of cultivars of rose has been reported previously, there are still difficulties encountered with shoot differentiation, rooting in vitro and establishment of plantlets in growing media which are dependent on mineral nutrients and hormonal factors employed in vitro propagation.

Shoot formation is strongly dependent on the presence of cytokinin, while auxin only had a modifying effect on the cytokinin influence. A narrow concentration range of BA was reported to be suitable in previous studies with a large number of types and cultivars of rose (Khosh-Khui and Sink, 1982).

Elevated levels of BA apparently caused stunting of shoots (Hasegawa, 1980) and had a negative effect on subsequent rooting (Bressan et al., 1982). In this study, BAP at $1.0 \mathrm{gm} / \mathrm{l}$ in the presence of $0.5 \mathrm{mg} / \mathrm{l}$ IAA was suitable for micropropagation of three cultivars of rose. Moreover, these results agree 
with those reported by Gerard et al. (1989) who found that BA at $1.0 \mathrm{mg} / \mathrm{l}$ was suitable for micropropagation of three different types of rose.

In general, root initiation is affected by the culture conditions during shoot multiplication stage and prior to transfer to the rooting medium. This effect might be a consequence of residual BA in the shoot, accumulated from the multiplication medium, which can either promote or inhibit root initiation. The obtained results also indicated that BAP applied during multiplication stage especially at high concentrations $(1.0$ and $2.0 \mathrm{mg} / \mathrm{l})$ reduced rooting and acclimatization capacities of rose plantlets. Similar tendendencies were observed in case of Nephrolepis exaltata by Batlle and Aldrufeu (1985). In the same line, Maene and Debergh (1985) advice to apply BAP at very low concentration before rooting in order to improve rooting and adaptation capacities.

After the effect of cytokinins on rooting may be the result of its negative influence on the size of formed shoots. In addition, cytokinins well known tendency to be a stimulator factor for branching and at high concentrations, the formation of many small shoots (Fox, 1976). Maene and Debergh (1983) once again stated that shorter shoots significantly resulted in bad rooting compared with the longer ones. Dencso (1985), Paques and Boxus (1985) proved that cytokinins applied in high concentration and especially in the form of BAP stimulate vitrification, which subsequently reduces the survival of such shoots.

Rose root formation appears to be determined by a complex of plant environmental, nutritional and hormonal factors. Rooting is strongly reduced or completely blocked if certain requirements are not fulfilled. To achieve optimum rooting, it is necessary to known just how to balance the many factors described for the cultivar concerned. The results of this study suggested that rose explants well grown on medium containing low concentration from IAA $(0.3 \mathrm{mg} / \mathrm{l})$ which produced the highest rooting percentage, the highest number of roots and tallest roots. Similar results have been reported by Hu and Wang (1983) who found that root initiation may be facilitated by adding a low concentration of NAA or IAA to the medium. On the other hand, it was observed that high auxins concentrations greatly decreased the percentage of rooted plantlets, delay root initiation, stimulate profuse callus production and inhibit root formation and elongation. In the same lines, Lane (1978) reported that high auxin levels sometimes interfere with rooting and inhibit full root development. Greenwood and Berlyn (1973) indicated that the use of NAA and IAA at a higher concentration than that of the optimum one inhibits rooting. Lingappa (1957) who used high concentrations of NAA $\geq 1 \mathrm{mg} / \mathrm{l}$ in the medium, which exerted a beneficial effect on the callus proliferation, but not on the root formation.

The roots formation and Successful transfer to soil of rose shoots appear to be enhanced by a low level of IAA. In this study, presented results indicated that the root formation and successful transfer of plantlets were enhanced by a low level of IAA. While, the survival percentage of rooted plants on rooting media contained high concentrations of IAA (1.0 and 3.0 $\mathrm{mg} / \mathrm{l}$ ) was significantly low. Similar results were obtained by Lane's (1978) 
observed that high auxin level sometimes interfere with rooting and inhibit full root development.

In this concern, the reason of low survival rate (with visible symptoms of leaf senescence) can be due to the increase of ethylene production by shoots being rooted on the media containing a high concentration of IAA. Auxins are well known as stimulators of ethylene synthesis in plant systems (Yang, 1980). This reducing effect of IAA on root elongation was previously confirmed by Hasegawa (1980) and Maene and Debergh (1983) in the case of Rose and Cordyline, respectively.

Preliminary results from the present experiment to determine the suitability of rose cvs. for in vitro propagation varied from cultivar to cultivar within the species. Athena cv. showed the latest adaptability to in vitro culturing, while Red Success cv. showed the fastest growth and development rate.

\section{REFERENCES}

Batlle, A. and A. Aldrufeu (1985). Materials of symposium on in vitro problems. Gembloux, Belgium, Posters: 51.

Bressan, P.H.; Y.J. Kim; S.E. Hyndman; P.M., Hasegawa and R.A., Bressan (1982). Factors affecting in vitro propagation of rose. J. Amer. Sco. Hort. Sci., 107(6): $979-990$.

Dencso, I. (1985). Materials of Symposium on in vitro problems. Gembloux, Belgium. Acta Horticulturae, (212): 167 - 176.

Elliot, R.F. (1970). Axenic culture of meristem tips of Rosa multifora. Planta, 95: $183-186$.

Fox, J.E. (1976). Fizjologia Wzrostu I Rozwoju Roslin, PWRIL, Warszaw: 90 $-125$.

Gerard, C.D., B.R. Clare, D.C., Angela and H.S.R., David (1989). Micropropagation of floribunda, ground cover and miniature roses. Plant Cell, Tissue and Organ Culture, 19: $55-64$.

Greenwood, M.S. and G.P., Berlyen (1973). Amer. J. Bot., 60: 42 - 47.

Hasegawa, P.M. (1979). In vitro propagation of rose. Hort Science, 14(5): $610-612$

Hasegawa, P.M. (1980). Factors affecting shoot and root initiation from cultured rose shoot tips. J. Amer. Soc. Hort. Sci., 105: 216 - 220.

Hu, C.Y. and P.J. Wang (1983). In Handbook of Plant Cell Culture, Vol. 1. Techniques for Propagation and Breeding, (Eds. D.A. Evans, V.R. Sharp, P.V. Ammirato, and Y. Yamada), pp. $127-227$. New York.

Hussein, H.A.A. and E.K. Toth (1993). In vitro propagation of some Rosa hybrida L. cultivars. J. Agric. Sci. Mansoura Univ., 18(7): $2093-2105$.

Jacobs, G.; P. Allan and C.H. Borman (1969). Tissue culture studies on rose: Use of shoot tip explants. I. Auxin: cytokinin effects. Agroplantae, 1: $179-188$.

Khosh-Khui, M. and K.C. Sink (1982). Micropropagation of new and old world rose species. Sco. Hort., 17: $372-376$.

Lane, W.D. (1978). Regeneration of Apple plants from shoot meristem tips. Plant Sci. Lett., 13: $281-285$.

Lingappa, Y. (1957). Amer. J. Bot., 44: 419 - 423.

Maene, L.M. and P.C., Debergh (1983). Rooting of tissue cultured plants under in vivo conditions. Acta Horticulturae, 131: $201-208$.

Maene, L.J. and P.C., Debergh (1985). Optimalisation of the transfer of tissue cultured shoots to in vivo conditions. Acta Horticulturae, 212: $335-$ 348. 
Martin, C.M.; R. Carre and C.R. Vernoy (1981). La multiplication végétative in vitro des végétaux ligneux cultivés: Cas des rosiers C.R. Acad. Sc. Paris, 293: $175-177$.

Murashige, T. and F. Skoog (1962). A revised medium for rapid growth and bioassays with tobacco tissue cultures. Physiol. Plant., 15: $437-497$.

Paques, M. and $\mathrm{Ph}$, Boxus (1985). Symposium on in vitro problems. Gembloux, Belgium, Lectures, Acta Horticulturae, (212): 155 - 166.

Quoirin, M. and Ph. Lepoivre (1977). Etude de miliex adaptex aux cultures in vitro de prunus. Acta Hortic., 78: 437 - 442.

SAS Institute (2000). SAS/STAT User's Guide: Statistics. Ver 8, Fourth Edition SAS Institute Inc., Cary, NC.

Skirvin, R.M. and M.C. Chu (1979). In vitro propagation of "Forever Yours rose". Hort Science, 14(5): $608-610$.

Yang, S.F. (1980). Hort Science 15(3): 238 - 243.

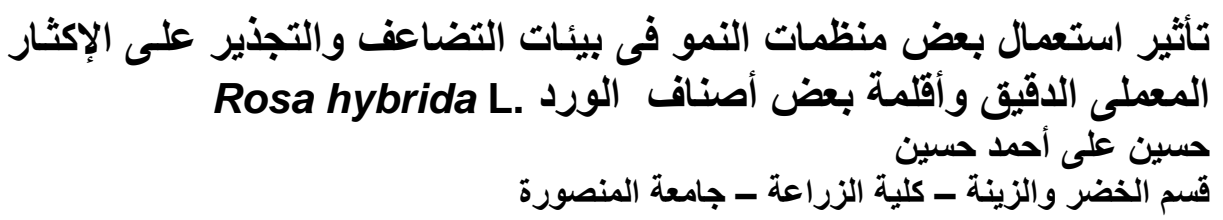

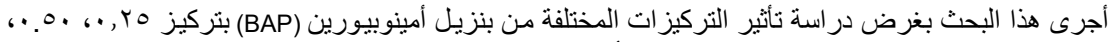

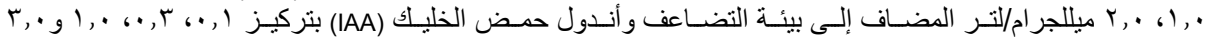

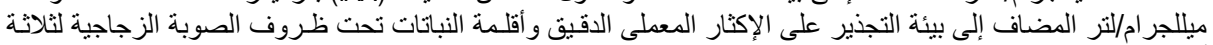

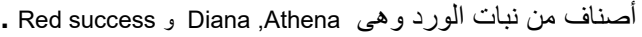
ولدر اسة مدى إستجابة أصناف الورد الثلاثنة إلى محتويات البيئة الغذائية فصلت القمم النامية بطول بيتر اوح بين

10

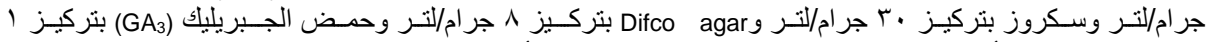

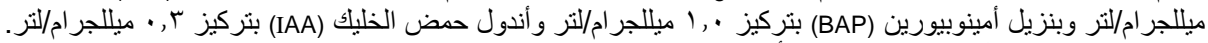

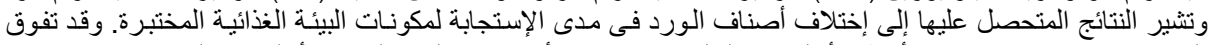

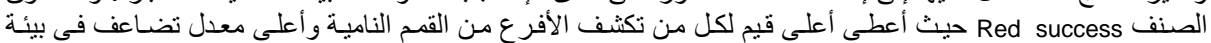

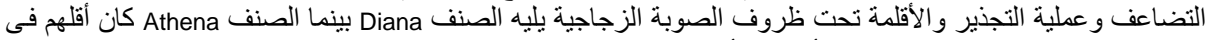

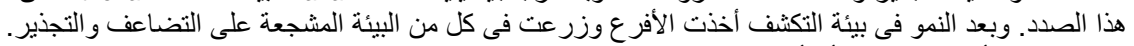

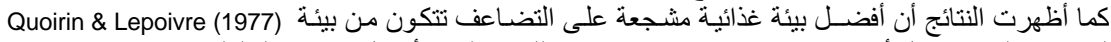

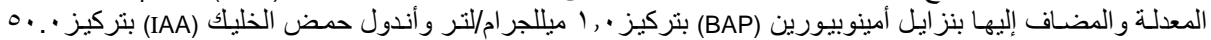

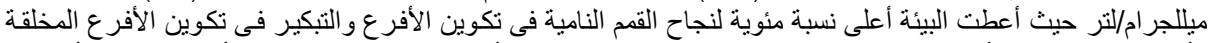

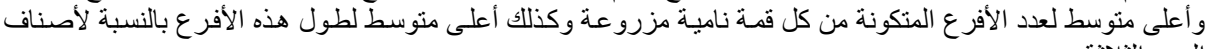
الورد الثناثة.

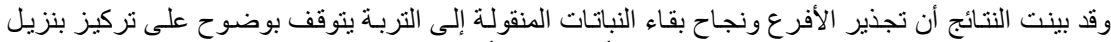

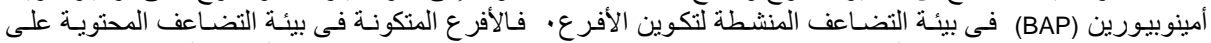

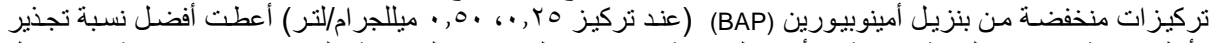

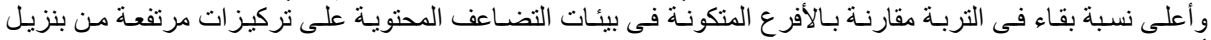

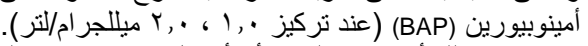

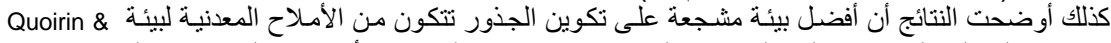

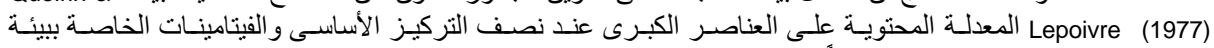

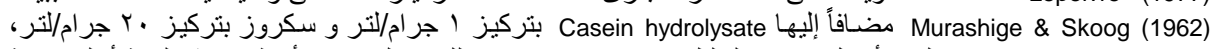
مifco agar

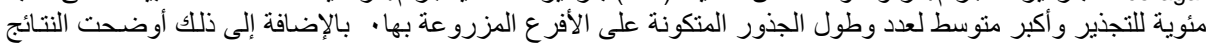

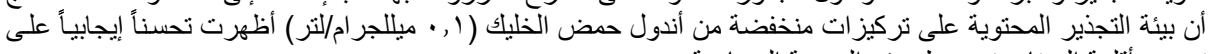
تحسين أقلمة النبيتات تحت ظريز التروف على تركيز الصوبة الزجاجية.

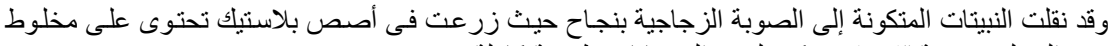

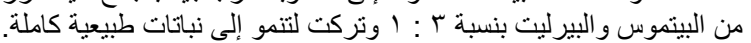


J. Agric. Sci. Mansoura Univ., 32 (4), April, 2007 
J. Agric. Sci. Mansoura Univ., 32 (4): 2849 - 2862, 2007

Table (1): Effect of different cultivars on shoots proliferation of Rosa hybrida L. explants after incubation for 4 weeks on proliferation medium.

\begin{tabular}{|c|c|c|c|c|c|c|}
\hline $\begin{array}{l}\text { Characters } \\
\text { Treatments }\end{array}$ & $\begin{array}{c}\text { Contamination } \\
\text { percentage } \\
\text { of shoot tip explants } \\
(\%)\end{array}$ & $\begin{array}{l}\text { Survival } \\
\text { percentage } \\
\text { of shoot tip } \\
\text { explants } \\
(\%)\end{array}$ & $\begin{array}{c}\text { Number of days } \\
\text { until appearance } \\
\text { of visible formed } \\
\text { leaves per explant } \\
\text { (days) }\end{array}$ & $\begin{array}{c}\text { Percentage } \\
\text { of explants } \\
\text { which formed } \\
\text { shoots per } \\
\text { explant (\%) }\end{array}$ & $\begin{array}{l}\text { Average } \\
\text { number } \\
\text { of } \\
\text { shoots } \\
\text { per } \\
\text { explant }\end{array}$ & $\begin{array}{l}\text { Average } \\
\text { length of } \\
\text { shoot per } \\
\text { explant } \\
\text { (cm) }\end{array}$ \\
\hline $\begin{array}{l}\text { Cultivars: } \\
\text { Athena } \\
\text { Diana } \\
\text { Red Success }\end{array}$ & $\begin{array}{c}14.30 \\
0.00 \\
7.10 \\
\end{array}$ & $\begin{array}{l}92.85 \\
92.85 \\
96.11 \\
\end{array}$ & $\begin{array}{c}10.80 \\
9.73 \\
9.30 \\
\end{array}$ & $\begin{array}{l}88.70 \\
96.43 \\
92.30 \\
\end{array}$ & $\begin{array}{l}2.09 \\
1.88 \\
2.54\end{array}$ & $\begin{array}{l}1.11 \\
1.60 \\
1.71 \\
\end{array}$ \\
\hline $\begin{array}{l}\text { L.S.D. at 5\% } \\
\text { Cultivars }\end{array}$ & 1.80 & 1.35 & 0.92 & 1.33 & 0.39 & 0.31 \\
\hline
\end{tabular}


Table (2): Effect of different cultivars and concentrations of 6-benzylaminopurine (BAP) and their interaction on shoots multiplication of Rosa hybrida L. after incubation for 4 weeks on multiplication media.

\begin{tabular}{|c|c|c|c|c|c|}
\hline Characters & $\begin{array}{c}\text { Survival percentage } \\
\text { of shoot tip explants } \\
(\%)\end{array}$ & $\begin{array}{l}\text { Number of days until } \\
\text { appearance of visible } \\
\text { formed shoots per explant }\end{array}$ & $\begin{array}{c}\text { Percentage of } \\
\text { explants which } \\
\text { formed shoots per } \\
\text { explant (\%) } \\
\end{array}$ & $\begin{array}{c}\text { Average } \\
\text { number of } \\
\text { shoots per } \\
\text { explant } \\
\end{array}$ & $\begin{array}{l}\text { Average length } \\
\text { of shoot per } \\
\text { explant }(\mathrm{cm})\end{array}$ \\
\hline \multicolumn{6}{|l|}{ Cultivars: } \\
\hline $\begin{array}{l}\text { Athena } \\
\text { Diana } \\
\text { Red Success } \\
\end{array}$ & $\begin{array}{l}96.50 \\
92.50 \\
98.95\end{array}$ & $\begin{array}{l}11.24 \\
10.86 \\
10.42\end{array}$ & $\begin{array}{l}88.13 \\
90.12 \\
96.82\end{array}$ & $\begin{array}{l}2.18 \\
2.33 \\
2.62\end{array}$ & $\begin{array}{l}0.83 \\
1.09 \\
1.00\end{array}$ \\
\hline \multicolumn{6}{|l|}{ 6-benzylaminopurine (BAP) at $\mathrm{mg} / \mathrm{L}$ : } \\
\hline $\begin{array}{l}0.25 \\
0.50 \\
1.00 \\
2.00\end{array}$ & $\begin{array}{c}100.00 \\
100.00 \\
100.00 \\
83.93 \\
\end{array}$ & $\begin{array}{c}11.01 \\
10.67 \\
9.88 \\
11.79 \\
\end{array}$ & $\begin{array}{l}92.43 \\
95.83 \\
97.90 \\
80.60 \\
\end{array}$ & $\begin{array}{l}2.19 \\
2.44 \\
2.85 \\
2.02 \\
\end{array}$ & $\begin{array}{l}0.93 \\
0.98 \\
1.14 \\
0.82 \\
\end{array}$ \\
\hline \multicolumn{6}{|l|}{ Cultivars $\times$ BAP concentrations } \\
\hline $\begin{array}{l}\text { Athena } \times 0.25 \mathrm{mg} / \mathrm{l} \mathrm{BAP} \\
\text { Diana } \times 0.25 \mathrm{mg} / \mathrm{l} \text { BAP } \\
\text { Red Success } \times 0.25 \mathrm{mg} / \mathrm{l} \mathrm{BAP}\end{array}$ & $\begin{array}{l}100.00 \\
100.00 \\
100.00\end{array}$ & $\begin{array}{l}11.45 \\
11.03 \\
10.55\end{array}$ & $\begin{array}{l}94.80 \\
85.70 \\
96.80\end{array}$ & $\begin{array}{l}1.98 \\
2.20 \\
2.40\end{array}$ & $\begin{array}{l}0.83 \\
0.98 \\
1.00\end{array}$ \\
\hline $\begin{array}{l}\text { Athena } \times 0.50 \mathrm{mg} / \mathrm{l} \mathrm{BAP} \\
\text { Diana } \times 0.50 \mathrm{mg} / \mathrm{l} \text { BAP } \\
\text { Red Success } \times 0.50 \mathrm{mg} / \mathrm{l} \text { BAP }\end{array}$ & $\begin{array}{l}100.00 \\
100.00 \\
100.00\end{array}$ & $\begin{array}{l}11.03 \\
10.53 \\
10.45\end{array}$ & $\begin{array}{l}95.70 \\
94.80 \\
97.00\end{array}$ & $\begin{array}{l}2.30 \\
2.38 \\
2.65\end{array}$ & $\begin{array}{l}0.83 \\
1.18 \\
0.95\end{array}$ \\
\hline $\begin{array}{l}\text { Athena } \times 1.00 \mathrm{mg} / \mathrm{l} \mathrm{BAP} \\
\text { Diana } \times 1.00 \mathrm{mg} / \mathrm{lBAP} \\
\text { Red Success } \times 1.00 \mathrm{mg} / \mathrm{l} \mathrm{BAP}\end{array}$ & $\begin{array}{l}100.00 \\
100.00 \\
100.00\end{array}$ & $\begin{array}{l}10.55 \\
9.95 \\
9.13\end{array}$ & $\begin{array}{l}98.70 \\
96.30 \\
98.90\end{array}$ & $\begin{array}{l}2.63 \\
2.63 \\
3.30\end{array}$ & $\begin{array}{l}0.83 \\
1.35 \\
1.25\end{array}$ \\
\hline $\begin{array}{l}\text { Athena } \times 2.00 \mathrm{mg} / \mathrm{l} \mathrm{BAP} \\
\text { Diana } \times 2.00 \mathrm{mg} / \mathrm{l} \text { BAP } \\
\text { Red Success } \times 2.00 \mathrm{mg} / \mathrm{l} \mathrm{BAP}\end{array}$ & $\begin{array}{l}86.00 \\
70.00 \\
95.80\end{array}$ & $\begin{array}{l}11.95 \\
11.95 \\
11.48\end{array}$ & $\begin{array}{l}63.00 \\
83.70 \\
94.00\end{array}$ & $\begin{array}{l}1.80 \\
1.88 \\
2.13\end{array}$ & $\begin{array}{l}0.83 \\
0.88 \\
0.75\end{array}$ \\
\hline \multicolumn{6}{|l|}{ L.S.D. at 5\% } \\
\hline $\begin{array}{l}\text { Cultivars } \\
\text { BAP concentrations } \\
\text { Cultivars } \text { x BAP concentration }\end{array}$ & $\begin{array}{l}0.19 \\
0.22 \\
0.38\end{array}$ & $\begin{array}{l}0.48 \\
0.56 \\
0.96\end{array}$ & $\begin{array}{l}0.21 \\
0.24 \\
0.38\end{array}$ & $\begin{array}{l}0.30 \\
0.35 \\
0.60\end{array}$ & $\begin{array}{l}0.09 \\
0.11 \\
0.18\end{array}$ \\
\hline
\end{tabular}


Table (3): Effect of different cultivars and concentrations of 6-benzylaminopurine (BAP) on rooting and survival percentages of Rosa hybrida L. explants grown on rooting medium containing IAA at $0.5 \mathrm{mg} / \mathrm{l}$ for 2 weeks

\begin{tabular}{|c|c|c|c|c|c|c|c|c|c|c|c|c|c|c|c|}
\hline \multirow{4}{*}{ Treatments } & \multicolumn{15}{|c|}{ Tested cultivars } \\
\hline & \multicolumn{5}{|c|}{ Athena } & \multicolumn{5}{|c|}{ Diana } & \multicolumn{5}{|c|}{ Red Success } \\
\hline & \multicolumn{15}{|c|}{ 6-benzylaminopurine (BAP) (mg/l) } \\
\hline & 0.25 & 0.50 & 1.0 & 2.0 & Mean & 0.25 & 0.50 & 1.0 & 2.0 & Mean & 0.25 & 0.50 & 1.0 & 2.0 & Mean \\
\hline Rooting percentage \% & 71.5 & 68.5 & 47.0 & 37.0 & 56.0 & 63.5 & 72.0 & 52.0 & 44.0 & 57.9 & 81.5 & 83.4 & 60.7 & 39.0 & 66.0 \\
\hline Survival percentage $\%$ & 73.0 & 53.0 & 58.0 & 36.5 & 55.1 & 73.5 & 63.0 & 46.0 & 31.0 & 53.4 & 78.0 & 88.0 & 66.0 & 49.0 & 70.3 \\
\hline \multicolumn{16}{|l|}{ L.S.D. at $5 \%$} \\
\hline For rooting (\%): & \multicolumn{5}{|c|}{ Cultivars 1.195} & \multicolumn{5}{|c|}{ BAP concent. 1.38} & \multicolumn{5}{|c|}{ Cultivars x BAP concent. 1.67} \\
\hline For survival (\%): & \multicolumn{5}{|c|}{ Cultivars 1.07} & \multicolumn{5}{|c|}{ BAP concent. 1.24} & \multicolumn{5}{|c|}{ Cultivars x BAP concent. 1.50} \\
\hline
\end{tabular}


Table (4): Effect of different cultivars and concentrations of Indole-3-acetic acid (IAA) on rooting and survival percentage of Rosa hybrida L. explants after incubation for 2 weeks on rooting media

\begin{tabular}{|c|c|c|c|c|c|}
\hline Characters & $\begin{array}{c}\text { Percentage } \\
\text { of shoot explants which } \\
\text { formed roots per explant } \\
(\%)\end{array}$ & $\begin{array}{l}\text { Number of days until } \\
\text { appearance of visible } \\
\text { formed roots per } \\
\text { explant } \\
\end{array}$ & $\begin{array}{c}\text { Average } \\
\text { number of roots } \\
\text { per explant }\end{array}$ & $\begin{array}{l}\text { Average length of } \\
\text { roots per explant } \\
\text { (cm) }\end{array}$ & $\begin{array}{c}\text { Survival } \\
\text { percentage of } \\
\text { rooted plantlets } \\
(\%) \\
\end{array}$ \\
\hline \multicolumn{6}{|l|}{ Cultivars: } \\
\hline Athena & 35.93 & 12.47 & 1.12 & 0.45 & 37.5 \\
\hline Diana & 41.28 & 10.22 & 1.74 & 0.87 & 37.5 \\
\hline Red Success & 45.10 & 10.40 & 3.49 & 0.64 & 48.4 \\
\hline \multicolumn{6}{|c|}{ Indole-3-acetic acid (IAA) at mg/l } \\
\hline$x_{1}$ & 31.10 & 9.04 & 2.37 & 0.78 & 66.80 \\
\hline 0.30 & 65.60 & 10.43 & 2.89 & 0.89 & 46.90 \\
\hline 1.00 & 60.00 & 11.51 & 1.81 & 0.63 & 32.00 \\
\hline 3.00 & 6.37 & 13.14 & 1.40 & 0.30 & 18.90 \\
\hline \multicolumn{6}{|l|}{ Cultivars $x$ IAA concentrations } \\
\hline Athena $\times 0.10 \mathrm{mg} / \mathrm{l} \mathrm{IAA}$ & 33.30 & 10.00 & 1.15 & 0.42 & 65.00 \\
\hline Diana $\times 0.10 \mathrm{mg} / \mathrm{IAA}$ & 20.00 & 8.00 & 1.97 & 1.10 & 66.70 \\
\hline Red Success $\times 0.10 \mathrm{mg} / \mathrm{l}$ IAA & 40.00 & 9.13 & 3.97 & 0.82 & 68.75 \\
\hline Athena $\times 0.30 \mathrm{mg} / \mathrm{I} \mathrm{IAA}$ & 66.80 & 10.95 & 1.32 & 0.52 & 40.00 \\
\hline Diana $\times 0.30 \mathrm{mg} / \mathrm{l} \mathrm{IAA}$ & 80.60 & 9.95 & 2.37 & 1.22 & 44.40 \\
\hline Red Success $\times 0.30 \mathrm{mg} / \mathrm{IAA}$ & 50.00 & 10.37 & 4.97 & 0.92 & 56.25 \\
\hline Athena $\times 1.00 \mathrm{mg} / \mathrm{l} \mathrm{IAA}$ & 40.00 & 13.02 & 1.00 & 0.42 & 30.00 \\
\hline Diana $\times 1.00 \mathrm{mg} / \mathrm{I}$ IAA & 60.00 & 10.95 & 1.37 & 0.87 & 22.20 \\
\hline Red Success x $1.00 \mathrm{mg} / \mathrm{l} \mathrm{IAA}$ & 80.00 & 10.55 & 3.05 & 0.60 & 43.75 \\
\hline Athena x $3.00 \mathrm{mg} / \mathrm{IAA}$ & 3.60 & 15.90 & 1.00 & 0.43 & 15.00 \\
\hline Diana $\times 3.00 \mathrm{mg} / \mathrm{IAA}$ & 5.10 & 11.97 & 1.22 & 0.28 & 16.70 \\
\hline Red Success $\times 3.00 \mathrm{mg} / \mathrm{l} \mathrm{IAA}$ & 10.40 & 11.55 & $1 / 97$ & 0.20 & 25.00 \\
\hline \multicolumn{6}{|l|}{ L.S.D. at $5 \%$} \\
\hline Cultivars & 1.05 & 0.54 & 0.23 & 0.16 & 1.09 \\
\hline IAA concentrations & 1.21 & 0.63 & 0.28 & 0.16 & 1.26 \\
\hline Cultivars $\mathrm{x}$ IAA concentrations & 2.10 & 1.08 & 0.48 & 0.32 & 1.53 \\
\hline
\end{tabular}

